\title{
ResearchArticle
}

\section{Role of sucrose and raffinose in the desiccation sensitivity of Theobroma cacao seeds}

\author{
ABIS V. CHERUSSERY, P.G. RADHA, NABEESA SALIM AND K.M. JAYARAM
}

\begin{abstract}
SUMMARY
Freshly collected seeds of cocoa were desiccated at room temperature and germination rate moisture content, soluble carbohydrates etc were analysed in the samples collected at regular intervals. Cocoa seeds are highly recalcitrant and total lose of viability occurs within 6 days of storage at room temperature. There is progressive deterioration of integrity of the membrane component of the cellular system during desiccation. This is manifested as the enhanced leakage of electrolytes from the tissues. A significant increase in sucrose content was observed in the cocoa seed tissues during desiccation. Raffinose content in the seeds declined rapidly during desiccation. Sucrose is suggested to have a critical role in maintaining the integrity of the cell membrane during dehydration. HPLC analysis of sucrose and raffinose through successive stages of desiccation does not impart tolerance to dehydration. This is because of the crystallization of sucrose and the deficiency of raffinose to ameliorate it. The sucrose to raffinose ratio is critical to seed viability in cocoa than their absolute quantum. When the ratio goes beyond $8: 1$ the viability of the cocoa seeds commence to decline rapidly.
\end{abstract}

Key Words : Sucrose, Raffinose, Desiccation sensitivity, Theobroma cacao seeds

How to cite this article : Cherussery, Abis V., Radha, P.G., Salim, Nabeesa and Jayaram, K.M. (2015). Role of sucrose and raffinose in the desiccation sensitivity of Theobroma cacao seeds. Internat. J. Plant Sci., 10 (1): 38-42.

Article chronicle : Received : 26.06.2014; Revised : 16.11.2014; Accepted : 30.11 .2014

\section{MEMBERS OF THE RESEARCH FORUM}

Author to be contacted :

NABEESA SALIM, Division of Plant Physiology and Biochemistry, Department of Botany, University of Calicut, MALAPPURAM (KERALA) INDIA

Email: nabeesasalim@gmail.com

Address of the Co-authors:

ABIS V. CHERUSSERY, Department of Botany, Centre for Post Graduate Studies and Research, St. Joseph's College, Devagiri, CALICUT (KERALA) INDIA

P.G. RADHA, Department of Botany, Government Brennen College, Thalassery, KANNUR (KERALA) INDIA

K.M. JAYARAM, Division of Plant Physiology and Biochemistry, Department of Botany, University of Calicut, MALAPPURAM (KERALA) INDIA 